\title{
Quasi-film commercials. Analysis of selected car manufacturer campaigns
}

\author{
Introduction
}

Advertising content is an example of a persuasive message which influences the attitudes and behaviour of the receiver. Its main goal is to persuade people to purchase a specific product or service. Advertising can influence all components of someone's attitude: cognitive (convictions), emotional (emotions), and behavioural (actions) ${ }^{1}$. Market research, and media and consumer studies, which since the mid- $20^{\text {th }} \mathrm{c}$. have been conducted on a wide scale, indicate that "there is no such thing as a mass consumer, which is why advertising persuasion based on the assumptions of the mass needs and preferences of people has very limited effectiveness" ${ }^{\prime 2}$. Contemporary creators of advertising are aware of the need to identify specific target groups whom they intend to reach. To evoke an expected change, producers of commercials utilise a whole array of tools for exerting social influence: they strive to create a trustworthy character, they make sure the receivers can identify with the in-commercial character, they use attractive models and experts who can play the role of specialists, and they use catchy advertising slogans. Studies regarding the effectiveness of persuasive messages indicate, however, that an "excessively aggressive message may [...] result in a boomerang effect, i.e. a change of one's attitude which will be contrary to that which was intended"'. So, where should one seek a recipe for a commercial which is attractive for the receiver and, more importantly, effective? A solution might be

* Ph.D., e-mail: agabarczyk@gmail.com; Chair of Journalism and Social Communication, Faculty of Philology, University of Lodz.

${ }^{1}$ Vide: E. Aronson, T.D. Wilson, R.M. Akert, "Psychologia społeczna. Serce i umysł", transl. by A. Brzezińska, Wydawnictwo Zysk i S-ka, Poznan 1997.

${ }^{2}$ K. Janiszewska, R. Korsak, B. Kwarciak, P. Lewiński, M. Lisowska-Magdziarz, B. Nierenberg, E. Nowińska, R. Zimny, "Wiedza o reklamie. Od pomysłu do efektu”, Wydawnictwo Szkolne PWN, Warsaw-Bielsko-Biała 2009, p. 13.

${ }^{3}$ M. Tokarz, "Argumentacja, perswazja, manipulacja”, Gdańskie Wydawnictwo Psychologiczne, Gdansk 2006, p. 224. 
not to focus on the persuasive character of the language, but on the structure of the created messages. It seems difficult to argue against the statement that originality is necessary to grasp the attention of the contemporary receiver, bored with the host of advertising content "attacking" her/him from every angle. One of the more interesting methods of drawing viewers' attention is to develop film-like and TV drama-like commercials. Those relationships, still not that popular in Poland, though extremely interesting, can be observed at various levels: references to the style of selected film genres, creating series of episode-based stories, and utilising devices specific for the film narrative, e.g. the use of the "point of view" figure.

The goal of this article is to present selected examples of the relationships between commercials and film present in car manufacturer campaigns. In the Most Valuable Brands of 2016 summary presented by Brand Finance Global 500, the following car makes were listed as the most valuable ones: Toyota, BMW, and Mercedes-Benz ${ }^{4}$. For this article, I selected advertising campaigns of those makes which were listed at the top of the ranking. The analysis of the study material enabled me to identify two main forms of quasi-film commercials: a TV spot and a short film. Before discussing both types, I attempt to organise the main notions.

\section{Organising the main notions}

In the title of the article, I used the expression "quasi-film commercials", which is difficult to find in the typologies available in the subject literature. Researchers of advertising content use various criteria for organising this area of communication. Marian Golka is of the opinion that "the most obvious is the criterion of the applied means of broadcasting advertising content, which includes: press, radio, television, or poster advertising, advertising conducted through loudspeakers on public transport, post advertising, etc."5. Commercials which can be defined as quasi-film are definitely the closest to TV commercials, though the analysis of TV spots which are aired presently inclines one to differentiate between those two types because the medium of the former is not only the television screen - it can also be found in the virtual realm or in the form of digital discs. It would not be sufficient to consider only the medium as the basic criterion for identifying that type of advertising. Thus, the main focus is rather placed on the formation and the structure of the message and the material in which moving

\footnotetext{
${ }^{4}$ Vide: "Toyota najbardziej wartościową marką motoryzacyjną", http://www.carter.pl/articles/ toyota-najbardziej-wartosciowa-marka-motoryzacyjna.json [accessed on: 10.01.2017].

${ }^{5}$ M. Golka, "Świat reklamy”, Agencja Badawczo-Promocyjna ARTIA, Warsaw 1994, p. 15.
} 
images meet words and the broadly considered soundtrack (words, sound effects, music, etc.).

The subject literature includes, infrequently, mention of film commercials, which are defined as: "classic theatre commercials (played directly before a film), advertising content attached to a film on a DVD, or the particularly popular product placement, i.e. the pre-arranged and paid for inclusion of a particular

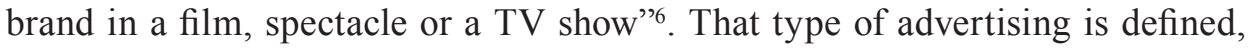
e.g. by indicating the place where it airs (theatres or equipment for playing DVDs). Such an understanding of film commercials was confirmed by a test of word associations ${ }^{7}$ which mainly "offers an opportunity to test brand names and study consumer attitudes towards a product, brand, and commercial" ", but, as it turned out, also notions and phenomena. The most common answers provided by the subjects were: a trailer, product placement, a spoiler, a theatre. Some also indicated the topic of advertising content, i.e. a film. According to some subjects, film commercials are those which can be called an advertisement of a film (a trailer). In the case of advertising content in which I am interested, its "filmness" refers to its form, structure, and the devices used, not the topic (thus, there is a limitation to only those instances advertising the latest film achievements). By introducing such a division, one can conclude that a commercial of a film can be a quasi-film, while a quasi-film commercial can, but it does not have to, refer to a film.

Therefore, what is the "quasi-film commercial" indicated in the title? What features should a piece of content possess so that it can be classified as this type of advertising? I sought answers to these questions together with students of journalism and social communication at the University of Lodz during a class entitled: Projektowanie reklamy - projektowanie narracji (Designing advertisements - Designing narration). Based on an analysis of dozens of commercials, I was able to develop an initial selection of that type of advertising:

- it was not limited to just one medium; it could had been aired on television or played at a theatre, it could had appeared on a website or on a DVD;

- it possesses a clear plot, i.e. a set of events, but the presented story is more important than the product or the service (the brand has often a subtle presence, e.g. in the ending) - that leads to the conclusion that not all commercials which use films as the medium can be termed quasi-films;

- its main goal is to evoke an emotional response from the viewer, for her/ him to become engaged in the story, to encourage her/him to pose the question: "what happens next?";

${ }^{6}$ A. Czubała, A. Jonas, T. Smoleń, J.W. Wiktor, "Marketing usług", Wolters Kluwer Polska, Warsaw 2012, p. 270.

${ }^{7}$ Conducted on 12 Feb 2017 via Facebook (on a sample of 50 people).

${ }^{8}$ J. Kall, "Reklama", Polskie Wydawnictwo Ekonomiczne, Warsaw 2002, p. 47. 
- it can refer to the conventions of specific film genres, e.g. a horror film (the exorcism-focussed commercial for Dirt Devil vacuum cleaners ${ }^{9}$ ) or a musical (the T-Mobile spot with Robert Lewandowski and Tomasz $\mathrm{Kot}^{10}$ );

- due to its length, it can possess the form of a TV spot (approx. 30 seconds) or a short film (even a few minutes long);

- the production crew often includes a film director (the best example of that was a series of short films with Clive Owen prepared by BMW; some of the directors included: John Woo, Tony Scott, and Guy Ritchie) ${ }^{11}$.

It should be stressed that commercials are extremely diverse. One Polish typology was proposed by Jacek Kall. He identified six types of commercials: demonstrations of operations, a piece of life, recommendations, lifestyle, humour, and animation ${ }^{12}$. As Piotr H. Lewiński has aptly noted: "that classification seems insufficient. Commercials feed on all literary, journalistic and film genres which they can adapt to their needs"13. Referring to Kall's classification and the proposal of Douglas J. Johnson ${ }^{14}$, the author of Retoryka reklamy proposed his own typology covering the following forms of commercials: a presentation, a fiction clip, an impression, a music video, a documentary, an animated film, music forms, quasitheatrical forms, journalistic forms, a game show, and an instruction clip ${ }^{15}$.

Lewiński's proposal covered eleven diverse categories. It seems that in order to identify them, the author used several criteria as it is difficult to find one clear division line. Thus, e.g.: a fiction clip, a documentary, and an animated film distinctly refer to various film works. Then, for a presentation and an impression what is important is the method of presenting a product, its role in the created text. In the case of a presentation, "what is being shown is the object of the commercial and its advantages are being listed"16, while an impression "often operates without

${ }^{9}$ Vide: https://www.youtube.com/watch?v=aGb8pMIeY6w [accessed on: 15.02.2017].

${ }^{10}$ Vide: https://www.youtube.com/watch?v=9BBqdPVf8kA [accessed on: 15.02.2017].

${ }^{11}$ A more recent example was a 12-minute commercial of the Prada fashion house entitled Past Forward directed by David O. Russell. Vide: "Wielkie kino jest w modzie. Reklama Prady przypomina film science fiction Alfreda Hitchcocka”, http://www.zetchilli.pl/Styl-zycia/Moda/ Wielkie-kino-jest-w-modzie-Reklama-Prady-przypomina-film-science-fiction-Alfreda-Hitchcocka-2744 [accessed on: 12.02.2017].

12 Vide: J. Kall, op. cit., pp. 128-134.

${ }^{13}$ P.H. Lewiński, "Retoryka reklamy”, Wydawnictwo Uniwersytetu Wrocławskiego, Wroclaw 1999, p. 153.

${ }^{14}$ The researcher identified the following types of TV commercials: a presentation, a demonstration, torture, a problem and a solution, a comparison, a drama scene, and a story. Vide: D.J. Johnson, “Advertising Today", Science Research Associates, Chicago 1978, pp. 216-217. As cited in: P.H. Lewiński, op. cit., pp. 153-154.

${ }^{15}$ Vide: P.H. Lewiński, op. cit., pp. 154-157.

${ }^{16}$ Ibid., p. 154. The author indicated that: "That type can possess two basic variants: either a product is presented in contrast to another product of the same category and that constitutes a comparison, or it is presented on its own and that constitutes a demonstration". Vide: ibid., p. 154. 
any words. Its goal is to build a positive atmosphere surrounding the product"17. There is also a group of commercials identified based on the types of arts to which they refer, e.g. music or quasi-theatrical forms.

I would like to consider commercials which can be defined as quasi-films in relation to films. By assuming such a perspective, I have placed three of the types identified by Lewiński at the centre of my focus: a fiction clip, a documentary, and an animated film (which correspond to types of films). The remaining types could appear within the scopes of the main three (e.g.: among music forms the quoted author included a musical, which is, in fact, a film genre and, thus, could function as a fiction film). As I focus on the relationships between commercials and film, I proposed to identify two categories of thus understood quasi-film commercials: a commercial film spot and a commercial short film, which differ in terms of their duration. Both forms can become part of a larger whole, i.e. a series of commercials.

\section{Commercial film spot}

The commercial film spot is the main type of quasi-film commercial. A spot is one of the most common forms of TV commercials (along with an advertising screen, a commercial programme, and product placement). I consider spots as "short, usually 30 -second-long clips presenting specific goods, their advantages and possible applications. They are aired between TV programmes, and during them on private television stations. They can take the form of individual spots (a stand-alone commercial appearing just once in a given block not related to any other commercial), divided commercials (two related spots divided by a commercial of a completely different product), or commercial series (a series of spots slowly revealing new advantages of goods or services, their possible applications, or even 'mysteries' not presenting the advertised product directly, but rather leading the viewer to its name)"18.

A film spot usually takes the form of the fiction clip identified by Lewiński. That type of advertising message "tells a story associated with the advertised product, but, unlike in the case of a presentation, the product is not its main actor, though it plays a key role"19. A fiction clip can take on various forms; the author himself identified several: a realistic clip, a drama, a love story, a horror clip, a historical clip,

\footnotetext{
${ }^{17}$ Ibid., p. 155.

${ }^{18}$ M. Bronowicz, "Komunikacja wizualna: Public relations. Reklama. Branding”, Wydawnictwo Astrum, Wroclaw 2014, pp. 106-107.

${ }^{19}$ P.H. Lewiński, op. cit., p. 154.
} 
an anecdote, an adventure clip, or pure nonsens $\mathrm{e}^{20}$. The presented story is sometimes inspired by films, e.g. there appear references to the conventions of film genres.

Among the spots present in the advertising campaigns of the Toyota car manufacturer, one can find some which clearly refer to film genres. One of the more distinct examples was a commercial entitled Loch Ness (Toyota Vios) ${ }^{21}$, which referred to the convention of a horror film. Its character faced the monster that allegedly inhabits the Scottish lake. In that version of the story, which consisted of only 5 shots, the monster drew its victims in, evoking in them an interest in a car (or actually a stencil dummy) parked on the shore of the lake. Elements of comedy-drama can be found in a spot entitled Funny Cat ${ }^{22}$, the message of which amounted to the advertising slogan: Feel Good Inside. The montage of the leitmotif used in the commercial presented the growing love of the four-legged character to a vehicle which enabled him to safely reach the veterinary clinic. Another enjoyable commercial was the 2016 The Longest Chase ${ }^{23}$ (Toyota Prius), which utilised the poetics of an action comedy. It is worth mentioning that one could also identify in it the features characteristic of a heist film, the story of which develops along the line of a heist. An undeniable advantage of the spot was the inclusion of TV coverage of a chase, which made it more dynamic.

Mercedes advertising campaigns have also included spots which featured some references to film. Film characteristics were present in a commercial entitled I'm sorry $y^{24}$, which referred to dark comedy. A car equipped with an efficient braking system made death the subject of a joke. Its realistic convention was interrupted when the Grim Reaper took the passenger seat (the transition was marked with a change in the soundtrack). Another interesting instance was the modernised version of the tale of the tortoise and the arrogant hare, the sixty-second spot entitled Fable ${ }^{25}$. It was also the perfect example of a commercial referring to an animated film. The highest level was achieved by the car manufacturer in a spot entitled The Journey ${ }^{26}$, which resembled a drama film. The story, utilising a linear montage, of a young boy immediately drew the viewer's attention and engaged her/him emotionally, while the non-diegetic soundtrack of the journey perfectly constructed the mood. The frequent use of long shorts expanding the viewer's attention, and the interchangeable use of the worm's eye or bird's eye views enabled the viewer to see in the final scene of the commercial the vulnerability of the main protagonist. A Mercedes appears as late as in the penultimate shot, which "is presented in the spot as a family-focussed

\footnotetext{
${ }^{20}$ Vide: ibid., p. 155.

${ }^{21}$ Vide: https://www.youtube.com/watch?v=rAuL7NeNSA4 [accessed on: 15.02.2017].

${ }^{22}$ Vide: https://www.youtube.com/watch? $\mathrm{v}=$ grTXob6uzjE [accessed on: 15.02.2017].

${ }^{23}$ Vide: https://www.youtube.com/watch? $\mathrm{v}=$ EluvJby2baA [accessed on: 15.02.2017].

${ }^{24}$ Vide: https://www.youtube.com/watch? $\mathrm{v}=7 \mathrm{ziIOSr9YxQ}$ [accessed on: 15.02.2017].

${ }^{25}$ Vide: https://www.youtube.com/watch? $\mathrm{v}=\mathrm{oF}-\mathrm{p} 4 \mathrm{Dkv}$ Q [accessed on: 15.02.2017].

${ }^{26}$ Vide: https://www.youtube.com/watch?v=-V2vHSuUJog [accessed on: 15.02.2017].
} 
make enabling one to complete 'small journeys' and mainly connotes a sense of security associated with a 'safe return"'27.

One of the more interesting BMW commercials was Italy Wedding ${ }^{28}$. It resembled a gangster film, and it could had been an interesting example of a quasifilm commercial had it not been for the excessive display of the car make. The logo recurring in several close-ups distracted the viewer's attention, and it could even be off-putting in consecutive shots. A much better example was the Goldeneye ${ }^{29}$ commercial, which featured the star of the well-known James Bond series - Pierce Brosnan. BMW cars had already appeared on the big screen, and the cult films about 007 have been one of the best known examples of product placement ${ }^{30}$. The commercial also included genre markers of an historical film. The advertising campaigns of the German car manufacturer have featured some interesting commercials which referred to film, however, the majority of those were short films which will be discussed in a further part of the article.

Marian Golka noted that "a television commercial has at its disposal a rich array of means of expression" ${ }^{\prime 3}$. He considered the following as the more commonly used devices: reaching the receiver through several senses, utilising visual and sound symbols, illustrating texts by using film material, using logotypes, creating original characters (for a specific brand), and utilising literary or film characters and animation ${ }^{32}$. Similar means can appear in quasi-film commercials (some of the more noteworthy include: the co-occurrence of moving images, music, sound effects, captions, and the use of film characters -007 in the spot promoting BMW). In the case of the commercials which I focussed on, the relationship with film had to be stronger, an issue I tried to indicate using the examples of spots which referred to film genres.

\section{Commercial short film}

A short film is a more developed form than a 30 -second-long spot. Its length can be counted not in seconds but in minutes. Among the presented examples, there are productions with a duration from over two to even a dozen or so minutes. Thus the limit of the duration of a spot is extended (up to 120 seconds).

\footnotetext{
${ }^{27}$ W. Orzeł, "Rola narracji storytellingowej w reklamie", http://marketerplus.pl/teksty/artykuly/rola-narracji-storytellingowej-w-reklamie/ [accessed on: 12.02.2017].

${ }^{28}$ Vide: https://www.youtube.com/watch?v=U1NvJVSKZEQ [accessed on: 15.02.2017].

${ }^{29}$ Vide: https://www.youtube.com/watch?v=23VX_ZK6u8 [accessed on: 15.02.2017].

30 Vide: "Bond. James Bond. Licencja na reklamowanie", http://wyborcza.pl/1,76842,12742176,Bond __James_Bond__Licencja_na_reklamowanie.html [accessed on: 13.02.2017].

${ }^{31}$ M. Golka, op. cit., pp. 51-52.

${ }^{32}$ Vide: ibid., pp. 51-52.
} 
Toyota when preparing the advertising campaign for its Mirai model decided to refer to the cult film Back to the Future (1985) directed by Robert Zemeckis. The result was a five-minute commercial entitled Fuelled by Future ${ }^{33}$ starring Christopher Lloyd and Michael J. Fox (who originally played doctor Emmett Brown and Marty McFly). The same actors coupled with a reference to science fiction films were not only common features of those productions: "in the spot, instead of the legendary DeLorean which carried McFly into the future, there appeared a different car - a Toyota Mirai, the first hydrogen-powered production car. Thus, the commercial referred to the story of the film, which predicted the use of a completely new type of fuel" 34 .

However, the first commercial short film appeared much earlier than that. A breakthrough project and a real masterpiece was the The Hire campaign, which BMW started in 2001. At the turn of the 21st century, the car manufacturer decided to utilise the extensive possibilities offered by the internet: "instead of preparing a traditional advertising campaign, they decided to offer receivers an opportunity to discover their make in the digital world" 35 . Its executive producer was David Fincher (Fight Club, Zodiac, The Curious Case of Benjamin Button and The Girl with the Dragon Tattoo). The film series, prepared by several acclaimed directors, was published online at BMWfilms.com, which enabled the manufacturer to gather an audience of 14 million people in 2001. A disc version was available at BMW showrooms and as an attachment to Vanity Fair ${ }^{36}$.

Each of the films could be considered as a separate story, being a result of the creativity and the unbridled artistic freedom of the directors. The campaign consisted of: Ambush ${ }^{37}$ (2001) - directed by John Frankenheimer, Chosen ${ }^{38}$ (2001) - directed by Ang Lee, The Follow ${ }^{39}$ (2001) - directed by Wong KarWai, $\operatorname{Star}^{40}$ (2001) - directed by Guy Ritchie, Powder Keg ${ }^{41}$ (2001) - directed by

\footnotetext{
${ }^{33}$ Vide: https://www.youtube.com/watch?v=cbADBZktbac [accessed on: 15.02.2017].

34 "Bohaterowie 'Powrotu do przyszłości' reklamują Toyotę Mirai (wideo)", http://www.wirtualnemedia.pl/ artykul/bohaterowie-powrotu-do-przyszlosci-reklamuja-toyote-mirai-wideo [accessed on: 14.02.2017].

${ }^{35}$ K. Fog, Ch. Budtz, P. Munch, S. Blanchette, "Storytelling - narracja w reklamie i biznesie", transl. by J. Wasilewski, B. Brach, Saatchi\&Saatchi, Warsaw 2011, p. 161. "Studies showed that $85 \%$ of BMW clients used the internet to learn about its range prior to purchasing a car". Vide: ibid., p. 161.

${ }^{36}$ Vide: W. Kaczałek, "Clive Owen - zawodowiec w BMW”, http://autokult.pl/3337,clive-owen-zawodowiec-w-bmw,all [accessed on: 14.02.2017].

${ }^{37}$ Vide: https://www.youtube.com/watch?v=BsWXkuyIdoY [accessed on: 15.02.2017].

${ }^{38}$ Vide: https://www.youtube.com/watch? $\mathrm{v}=-\mathrm{znm}$ 6I4Ro0 [accessed on: 15.02.2017].

${ }^{39}$ Vide: https://www.youtube.com/watch?v=jFijgJf-NLE [accessed on: 15.02.2017].

${ }^{40}$ Vide: https://www.youtube.com/watch? $\mathrm{v}=$ jmvlk88i3NA [accessed on: 15.02.2017].

${ }^{41}$ Vide: https://www.youtube.com/watch?v=IDpe_tX0hMU [accessed on: 15.02.2017].
} 
Alejandro González Iñárritu, Hostage ${ }^{42}$ (2002) - directed by John Woo, Ticker ${ }^{43}$ (2002) - directed by Joe Carnahan and Beat the Devil ${ }^{44}$ (2002) - directed by Tony Scott. The series had a unifying feature - its protagonist (played by Clive Owen). He was a nameless master driver hired to perform seemingly impossible tasks (e.g. save a hostage $\mathrm{e}^{45}$ or drive a wounded war photographer across the Columbian border ${ }^{46}$ ). It must be noted that each film "is full of exciting car chases and breathtaking stunts indicating the unlimited capabilities of BMW models"47.

The innovative project prepared by BMW also had a unique structure to its advertising budget: " $90 \%$ of the money was designated for the production (two seasons cost 25 million dollars), with $10 \%$ on the promotion of the features in the media" ${ }^{48}$. Statistical data confirmed that it was worth the risk. In May of 2002 in the United States alone, BMW sales rose by $17.4 \%{ }^{49}$. What is noteworthy, recently the car manufacturer has fallen back on the over-a-decade-old campaign - in 2016, it produced a film entitled The Escape ${ }^{50}$ directed by Neill Blomkamp, who created District 9 (2009) and Elysium (2013).

The form longer than a TV spot has also been used by Mercedes-Benz. In 2002, the car manufacturer developed a two-and-a-half-minute-long film entitled Lucky Star ${ }^{51}$ directed by Michael Mann. It story "was developed around the character of Mr. H., a professional gambler, who worked for large casinos, and drew the attention of government agents" ${ }^{\prime 2}$. The cast included Benicio Del Toro (he has featured in, e.g.: Fear and Loathing in Las Vegas, 21 Grams, The Wolfman). The action film announced by the material was supposed to be broadcast on ITV, Channel 4 and in some theatres, yet it was never developed ${ }^{53}$. The trailer did not even for one moment include the logo of the car manufacturer or the name, which resulted in considerable interest in it. The campaign, which utilised the codes of a film trailer, could be considered a success: "the original director's version at the official website www.luckystar.com was viewed 50,000 times within four weeks. Mercedes received the data of 14,000 potential drivers, which led to 3,000 test drives" $" 54$.

\footnotetext{
${ }^{42}$ Vide: https://www.youtube.com/watch?v=VOzdhfLMk9c [accessed on: 15.02.2017].

${ }^{43}$ Vide: https://www.youtube.com/watch? $\mathrm{v}=$ XGivBHff7hQ [accessed on: 15.02.2017].

${ }^{44}$ Vide: https://www.youtube.com/watch?v=RAQLflcOrTk [accessed on: 15.02.2017].

45 "Hostage", 2002, directed by John Woo.

46 "Powder Keg", 2001, directed by Alejandro González Iñárritu.

${ }^{47}$ K. Fog, Ch. Budtz, P. Munch, S. Blanchette, op. cit., p. 162.

${ }^{48}$ W. Kaczałek, op. cit.

49 Vide: K. Fog, Ch. Budtz, P. Munch, S. Blanchette, op. cit., p. 163.

${ }^{50}$ Vide: https://www.youtube.com/watch?v=jzUFCQ-P1Zg [accessed on: 15.02.2017].

${ }^{51}$ Vide: https://www.youtube.com/watch?v=YoCLxp2W9xE [accessed on: 15.02.2017].

${ }^{52}$ K. Fog, Ch. Budtz, P. Munch, S. Blanchette, op. cit., p. 163.

${ }^{53}$ Vide: ibid., p. 163.

${ }^{54}$ Ibid., p. 164.
} 


\section{Final remarks}

The authors of Storytelling - narracja $w$ reklamie $i$ biznesie (narration in advertising and business) stated that at the beginning of the 21st C. "BMW set off on a search to finally eliminate the borderline between films, entertainment, and commercials" ${ }^{\prime 55}$. Today, it is possible to indicate many commercials which clearly emulate film. The advertising campaigns of all three analysed car manufacturers included both examples of spots or short forms which utilised the conventions of certain film genres: comedy, drama, and horror, and commercial short film with a duration of up to a dozen or so minutes distributed via websites or DVDs. Those productions could be classified as advertainment, i.e. a blend of advertising and entertainment, the goal of which is "to create for a product/brand such an entertainment context in the form of appropriate packaging (genre form) which would enable ease of consumption"56.

It should be noted that apart from the two indicated types of quasi-film commercials, there also appeared commercial series which J. Kall classified as new forms of TV commercials. In reality, their beginnings date as far back as the $1980 \mathrm{~s} .{ }^{57} \mathrm{~A}$ commercial series is "a whole series of commercials where consecutive instalments end in a screen which reads 'to be continued'. Thus viewers become engaged in watching the commercial not only for the sake of the product, but also due to its continuously unfinished content. The problem is for each commercial to nonetheless 'sell' the product communicating to the viewers the advantages of a specific brand"58. Such a form was used, e.g. for promoting the Renault Clio $(1991)^{59}$. The creators of the series referred to the viewers' emotions. By presenting the love fortunes of the beautiful Nicole (Estelle Skornik) and her father, they wanted to create a close relationship between the product and emotional accomplishments. Seven years later, during the presentation of a new version of the model - they decided that she will get married ${ }^{60}$. It was approximated that 23 million viewers tuned in to watch the ceremony ${ }^{61}$.

Based on the analyses of contemporary commercials, researchers have concluded that the next step could be full feature films ${ }^{62}$. Apparently it is not so distant as some might think because some attempts have already been made: "The

\footnotetext{
55 Ibid., p. 161.

${ }^{56}$ G. Ptaszek, "Rozrywka w służbie reklamy (advertainment), czyli jak uśpić czujność konsumenta", Naukowy Przeglad Dziennikarski 2015, Issue 4, p. 70.

${ }^{57}$ Vide: K. Fog, Ch. Budtz, P. Munch, S. Blanchette, op. cit., p. 154.

${ }^{58}$ J. Kall, op. cit., p. 134.

${ }^{59}$ One of the episodes: https://www.youtube.com/watch?v=WgBGDvgYekA [accessed on: 15.02.2017].

${ }^{60}$ Vide: https://www.youtube.com/watch?v=DwqEpwO-5PE [accessed on: 15.02.2017].

${ }^{61}$ Vide: K. Fog, Ch. Budtz, P. Munch, S. Blanchette, op. cit., p. 159.

${ }^{62}$ Vide: ibid., p. 164.
} 
first company to transform a commercial series into a feature film was the Danish mobile phone carrier Sonofon. It was the story of a naive and winsome peasant from the mountains called 'Polle', who did everything he could to grasp how a modern mobile phone works. The story became so popular that the company decided to expand it and finance the production of a film. In 2002, Polle Fiction was released on the big screen. It was one of the three top Danish films which sold the most tickets on the night of the première" ${ }^{33}$.

Quasi-film commercials constitute one of the more original trends, and are used more and more often by brands from various segments of the market. The receivers, tired with yet another presentation of the advantages of using a specific product (typical for, e.g. washing powder) or a dentist recommending the purchase of a specific toothpaste, expect something more. An engaging story, surprising turns of events, dynamic montage, surprise, ambiguity of the message - all that can be available in a commercial which draws on film devices, which emulates films, and which tries to become a film.

\section{Quoted commercials}

https://www.youtube.com/watch?v=23VX_ZK6u8 [accessed on: 15.02.2017]. https://www.youtube.com/watch?v=7ziIOSr9YxQ [accessed on: 15.02.2017]. https://www.youtube.com/watch?v=9BBqdPVf8kA [accessed on: 15.02.2017]. https://www.youtube.com/watch?v=aGb8pMIeY6w [accessed on: 15.02.2017]. https://www.youtube.com/watch?v=BsWXkuyIdoY [accessed on: 15.02.2017]. https://www.youtube.com/watch?v=cbADBZktbac [accessed on: 15.02.2017]. https://www.youtube.com/watch?v=DwqEpwO-5PE [accessed on: 15.02.2017]. https://www.youtube.com/watch?v=EluvJby2baA [accessed on: 15.02.2017]. https://www.youtube.com/watch?v=grTXob6uzjE [accessed on: 15.02.2017]. https://www.youtube.com/watch?v=IDpe_tX0hMU [accessed on: 15.02.2017]. https://www.youtube.com/watch?v=jFijgJf-NLE [accessed on: 15.02.2017]. https://www.youtube.com/watch?v=jmvlk88i3NA [accessed on: 15.02.2017]. https://www.youtube.com/watch?v=jzUFCQ-P1Zg [accessed on: 15.02.2017]. https:/www.youtube.com/watch?v=oF--p4Dkv_Q [accessed on: 15.02.2017]. https://www.youtube.com/watch?v=RAQLflcOrTk [accessed on: 15.02.2017]. https://www.youtube.com/watch? $\mathrm{v}=\mathrm{rAuL7NeNSA4}$ [accessed on: 15.02.2017]. https://www.youtube.com/watch?v=U1NvJVSKZEQ [accessed on: 15.02.2017]. https:/www.youtube.com/watch?v=-V2vHSuUJog [accessed on: 15.02.2017]. https://www.youtube.com/watch?v=VOzdhfLMk9c [accessed on: 15.02.2017]. https://www.youtube.com/watch? $\mathrm{v}=\mathrm{WgBGDvgYekA}$ [accessed on: 15.02.2017]. https://www.youtube.com/watch?v=XGivBHff7hQ [accessed on: 15.02.2017]. https://www.youtube.com/watch? $v=$ YoCLxp2W9xE [accessed on: 15.02.2017]. https://www.youtube.com/watch?v=-znm_6I4Ro0 [accessed on: 15.02.2017].

${ }^{63}$ Ibid. 


\section{Bibliography}

Aronson E., Wilson T.D., Akert R.M., "Psychologia społeczna. Serce i umysł”, transl. by A. Brzezińska, Wydawnictwo Zysk i S-ka, Poznan 1997.

Bronowicz M., "Komunikacja wizualna: Public relations. Reklama. Branding”, Wydawnictwo Astrum, Wroclaw 2014.

"Bohaterowie 'Powrotu do przyszłości' reklamują Toyotę Mirai (wideo)”, http://www.wirtualnemedia.pl/artykul/bohaterowie-powrotu-do-przyszlosci-reklamuja-toyote-mirai-wideo [accessed on: 14.02.2017].

“Bond. James Bond. Licencja na reklamowanie”, http://wyborcza.pl/1,76842,12742176,Bond_James_Bond_Licencja_na_reklamowanie.html [accessed on: 13.02.2017].

Czubała A., Jonas A., Smoleń T., Wiktor J.W., "Marketing usług”, Wolters Kluwer Polska, Warsaw 2012.

Fog K., Budtz Ch., Munch P., Blanchette S., "Storytelling - narracja w reklamie i biznesie”, transl. by J. Wasilewski, B. Brach, Saatchi\&Saatchi, Warsaw 2011.

Golka M., "Świat reklamy”, Agencja Badawczo-Promocyjna ARTIA, Warsaw 1994.

Janiszewska K., Korsak R., Kwarciak B., Lewiński P., Lisowska-Magdziarz M., Nierenberg B., Nowińska E., Zimny R., "Wiedza o reklamie. Od pomysłu do efektu”, Wydawnictwo Szkolne PWN, Warsaw-Bielsko-Biała 2009.

Johnson D.J., "Advertising Today”, Science Research Associates, Chicago 1978.

Kaczałek W., "Clive Owen - zawodowiec w BMW", http://autokult.pl/3337,clive-owen-zawodowiec-w-bmw,all [accessed on: 14.02.2017].

Kall J., "Reklama", Polskie Wydawnictwo Ekonomiczne, Warsaw 2002.

Lewiński P.H., "Retoryka reklamy”, Wydawnictwo Uniwersytetu Wrocławskiego, Wroclaw 1999.

Orzeł W., "Rola narracji storytellingowej w reklamie", http://marketerplus.pl/teksty/artykuly/rola-narracji-storytellingowej-w-reklamie/ [accessed on: 12.02.2017].

Ptaszek G., "Rozrywka w służbie reklamy (advertainment), czyli jak uśpić czujność konsumenta", Naukowy Przeglad Dziennikarski 2015, Issue 4, pp. 62-79.

Tokarz M., "Argumentacja, perswazja, manipulacja”, Gdańskie Wydawnictwo Psychologiczne, Gdansk 2006.

„Toyota najbardziej wartościową marką motoryzacyjną”, http://www.carter.pl/articles/toyota-najbardziej-wartosciowa-marka-motoryzacyjna.json [accessed on: 10.01.2017].

„Wielkie kino jest w modzie. Reklama Prady przypomina film science fiction Alfreda Hitchcocka", http://www.zetchilli.pl/Styl-zycia/Moda/Wielkie-kino-jest-w-modzie-Reklama-Prady-przypomina-film-science-fiction-Alfreda-Hitchcocka-2744 [accessed on: 12.02.2017]. 
Agnieszka Barczyk-Sitkowska

Quasi-film commercials. Analysis of selected car manufacturer campaigns

(Summary)

When seeking original forms of expression, contemporary commercials often reach for the achievements of film making. That is reflected in references to the conventions of certain film genres, and the references to particular films.

The goal of the article was to present selected examples of the relationships between commercials and film, which can be found in car manufacturer advertising campaigns (Toyota, BMW, and Mercedes-Benz). The analysis of the gathered study material enabled me to identify two forms of quasi-film commercials: a TV spot and a short film.

Keywords: commercial, film, quasi-film, commercial series, spot. 